\title{
TRADISIONALISME ISLAM SUATU KARAKTER DAN POLA PENGEMBANGAN ISLAM DI INDONESIA
}

\author{
Syamsuar Syam ${ }^{1}$ \\ ${ }^{1}$ UIN Imam Bonjol Padang \\ Email : Syamasuarsyam@Gmail.com
}

\begin{abstract}
Tradisionalisme merupakan salah satu karakter atau corak pemikiran yang ada dalam sejarah Islam. Corak pemikiran tradisionalisme dalam sejarah Islam telah menempatkan diri sebagai karakter mayoritas umat Islam. Namun dalam perkembangannya, tradisionalisme telah mengalami perubahan walau tidak terlalu kritis. Masyarakat Indonesia pada umumnya didominasi oleh corak berfikir tradisional. Organisasi seperti NU, Perti dan al-Washliyah merupakan bukti bahwa mayoritas masyarakat Indonesia menganut paham tradisional. Tradisional bukanlah berarti terbelakang atau kolot, tapi merupakan sebuah pola berfikir yang memiliki karakter tersendiri.
\end{abstract}

Keyword : karakter, tradisionalisme, Islam

\section{PENDAHULUAN}

Perkembangan pemikiran dalam Islam telah menimbulkan berbagai corak yang akhirnya menjadi sistem pergerakan pemikiran. Corak tersebut ada yang mengambil bentuk purifikasi (pemurnian), modernisasi, neo-modernisasi dan lain sebagainya. Bentuk-bentuk pergerakan pemikiran ini merupakan reaksi terhadap situasi dan kondisi yang dihadapi. Satu pergerakan pemikiran bisa saja sebagai reaksi terhadap gerakan pemikiran sebelumnya, seperti munculnya modernisme sebagai reaksi terhadap pola pikir gerakan tradisionalisme.

Dalam rentang sejarah, salah satu bentuk pergerakan yang tetap eksis dari dulu hingga sekarang dan hampir di seluruh dunia Islam adalah tradisionalisme. Tradisionalisme muncul atas dasar adanya keinginan untuk melestarikan ajaran Islam yang berdasarkan alQur'an dan al-Sunnah (yang dipahami secara tekstual). Tradisionalisme tidak saja berkembang di Timur Tengah, tapi juga sampai ke Indonesia. Hal ini merupakan bukti bahwa sebahagian besar umat Islam bercorak tradisional.

Di Indonesia paham tradisional diwakili oleh NU, Perti, alWashliyah dan Jama'ah Tabligh. Keempat kelompok ini dikategorikan sebagai kelompok tradisional yang terwujud dalam bentuk ide dan pemikirannya. Namun ada yang berpendapat menolak NU dikatakan sebagai tradisional, karena sebagian tokohnya cenderung berpaham rasional. Begitu pula dengan Perti dan al-Washliyah, mereka tidak menyebutnya sebagai tradisionalisme.

Untuk menjawab berbagai persoalan di atas penulis akan membahas tentang Tradisionalisme Islam di Indonesia yang meliputi pemikiran NU, Perti, al-Washliyah dan Jama'ah Tabligh. Dalam pembahasan tentang Tradisionalisme Islam di Indonesia akan dirangkum dalam 
pengertian tradisionalisme Islam, sejarah munculnya, paham dan gerakan tradisionalisme Islam di Indonesia.

\section{A. Pengertian Tradisionalisme Islam}

Kata tradisionalis berasal dari bahwa Inggris, tradition, yang diterjemahkan ke dalam bahasa Indonesia menjadi tradisi. (John M. Echols dan Hassan Shadily, 1979: 599) Dalam Kamus Umum Bahasa Indonesia, kata "tradisi" diartikan dengan adat, kepercayaan, kebiasaan, ajaran dan sebagainya yang turun temurun dari nenek moyang. (WJS Poerwadarminta, 1991: 1088) Dalam bahasa Arab kata tradisi biasanya diidentikkan dengan kata sunnah yang secara harfiah berarti jalan, tabi'at, perikehidupan. (Ahmad Warson Munawwir, 1997: 669). Sunnah dalam pengertian seperti ini sejalan dengan pengertian sunnah yang terdapat dalam hadits Nabi yang artinya: "Barang siapa yang mengadakan suatu kebiasaan yang baik, maka bagi orang itu akan mendapat pahala, dan pahala bagi orang yang melaksanakan kebiasaan tersebut." (Abuddin Nata, 2001:140)

Umumnya para ulama mengartikan kebiasaan yang baik adalah pemikiran dan kreativitas yang dapat membawa manfaat dan kemaslahatan bagi umat. Tradisi yang dimaksud di sini adalah mengadakan peringatan Maulid Nabi Muhammad Saw., Isra' Mi'raj, Tahun Baru Hijriyah dan sebagainya.

Kata sunnah merupakan istilah yang mengacu kepada segala sesuatu yang berasal dari Nabi, baik dalam bentuk ucapan, perbuatan maupun ketetapan. (Fathur Rahman, 1981 :13). Para ulama Muhadditsin baik dari kalangan kuno (salaf) maupun modern (khalaf) menyamakan pengertian sunnah dengan al-hadits, al-akhbar dan al- atsar. Sehingga kaum orientalis beranggapan bahwa orang yang berpegang teguh kepada al-Sunnah Rasulullah Saw dianggap sebagai tradisionalis.

Dalam perkembangan selanjutnya, tradisionalis tidak hanya ditujukan kepada orang yang berpegang teguh kepada al-Qur'an dan al-Sunnah saja (pemahaman secara tekstual), tapi termasuk "produk-produk" pemikiran (hasil ijtihad) para ulama yang dianggap unggul dan kokoh dalam berbagai bidang keilmuan seperti fiqh (hukum Islam), tafsir, teologi, tasawuf dan sebagainya. Pemikiran para ulama dalam berbagai bidang, pada hakekatnya merupakan hasil penalaran terhadap al-Qur'an dan alSunnah, sehingga hasil penalaran bukanlah sesuatu yang tidak boleh diubah. Dengan demikian kaum tradisionalis tidak membedakan antara ajaran yang terdapat dalam alQur'an dan al-Sunnah dengan ajaran yang merupakan hasil pemahaman terhadap keduanya. (Abuddin Nata, 2001: 142)

\section{Tradisionalisme}

merupakan ajaran filsafat dan teologi yang menolak adanya kesanggupan manusia menemukan kebenaran sendiri. Mereka berpendapat bahwa semua kebenaran harus diturunkan melalui perwahyuan Ilahi. Tradisional-isme pernah menjadi reaksi terhadap pandangan rasionalisme dan materialisme abad ke-19 di Barat, yang memutlakkan otonomi akal-budi, dengan usahausaha untuk kembali kepada kondisikondisi tradisionalis keagamaan, kesusilaan, sosial, dan politik.

Dalam arti yang lebih umum, tradisionalisme berarti penghargaan yang berlebihan pada tradisi, dan segala sesuatu yang terjadi masa lampau (dalam ilmu, seni, kepercayaan dan adat). (Hasan 
Shadily, 1984: 3608) Tradisionalisme dianggap juga sebagai dasar munculnya pemikiran konservatif. (Konservatif secara harfiah berasal dari bahasa Inggris conservative yang berarti kolot, kuno. Sedangkan dalam pengertian yang umum digunakan, konservatif mengacu kepada suatu keadaan atau sifat dari sesuatu yang tetap dan tidak mau mengikuti perubahan walaupun keadaan sudah menghendaki adanya perubahan tersebut. Hal ini muncul dari sikap yang terlampau berhati-hati dalam menerima hal-hal baru karena khawatir hal-hal baru tersebut merugikan kehidupan. Lihat: Hasan Shadily, 1984: 227)

Dengan demikian

tradisionalisme merupakan suatu paham yang berpegang teguh kepada al-Qur'an dan al-Sunnah dan mempertahankan hasil-hasil ijtihad para ulama terdahulu tanpa adanya analisis dan interpretasi yang mendalam. Istilah ini berasal dari bahasa Barat, yang menjadi label dalam bentuk pemikiran dan pergerakan dalam realita sejarah Islam dari dulu sampai sekarang. Pergerakan pemikiran tradisionalisme tidak hanya di Timur Tengah, tapi telah sampai ke Indonesia.

Secara umum

tradisionalisme Islam dalam realita sejarah memiliki ciri-ciri sebagai berikut:

1. Eksklusif (tertutup). Yang dimaksud di sini adalah tidak mau menerima pemikiran, pendapat dan saran yang berasal dari luar, terutama dalam bidang keagamaan. Hal ini timbul sebagai akibat dari sikap fanatisme golongan.

2. Tidak dapat membedakan ajaran dan non-ajaran. Tradisionalisme menganggap bahwa semua hal yang ada hubungannya dengan agama sebagai ajaran yang harus dipertahankan. Contoh: Menutup aurat (ajaran) dan pakaian (tidak ajaran). Mereka menganggap keduanya ajaran, sehingga tidak dapat diubah.

3. Berorientasi ke belakang. Tradisionalisme menilai bahwa berbagai keputusan hukum yang diambil oleh para ulama di masa lampau merupakan contoh ideal yang harus diikuti. Hal itu akibat terlalu mengagungkan para ulama masa lampau dengan segala atributnya yang tak mungkin dikalahkan oleh para ulama atau sarjana yang muncul belakangan.

4. Tekstualis-literalis.

Tradisionalisme cendrung memahami ayat-ayat al-Qur'an secara tekstual tanpa melihat latar belakang serta situasi sosial yang menyebabkan ayat-ayat tersebut diturunkan. Akibatnya jangkauan pemakaian suatu ayat sangat terbatas pada kasus-kasus tertentu saja, tanpa mampu mengkaitkan dengan perubahan situasi dan kondisi.

5. Kurang menghargai waktu. Tradisionalisme cendrung melakukan sesuatu tanpa memperhitungkan waktu. Misalnya, sistem pendidikan di Pesantren yang tidak memiliki pengembangan dan batasan kurukilum.

6. Tidak memahami sejarah masuknya agama. Sebelum Islam masuk ke Nusantara, sudah ditemui agama dan tradisi yang berkembang, ikut mewarnai tradisi dan paham keagamaan yang ada.

7. Mengutamakan perasaan dari akal pikiran. Mereka cenderung melakukan berbagai kegiatan yang diarahkan untuk konsumsi perasaan, walau mereka harus mengeluarkan biaya yang tidak 
sedikit, seperti kegiatan-kegiatan yang bersifat ritual keagamaan.

8. Bersifat jabariyah dan teosentris. Sikap pasrah, tunduk dan patuh pada Tuhan diiringi dengan keyakinan bahwa segala sesuatu jika Tuhan mengizinkan akan terjadi.

9. Kurang menghargai ilmu pengetahuan dan teknologi modern. Mereka sering melakukan pekerjaan dengan cara-cara seperti dahulu kala, tanpa disertai upaya untuk memperbaiki ke arah yang lebih efektif, efisien, cepat dan tepat.

10.Jumud dan statis. Mereka cendrung tidak mau mengikuti perubahan dan mempertahankan apa-apa yang dipandangnya sudah baik sejak dahulu, tanpa mempertanyakan secara kritis. (Hasan Shadily, 1984: 142-145)

Melihat ciri-ciri dan karakter di atas terkesan bahwa tradisionalis cenderung mempertahankan kebiasaan lama yang telah membudaya di tengahtengah masyarakat. Dalam tinjauan teologi, tradisionalisme akan dapat membawa kehidupan statis terhadap umat manusia. Manusia dianggap lemah dan harus menerima apa adanya (fatalistik).

Untuk Indonesia yang diwakili oleh Perti, NU, al-Wasyiliyah dan Jama'ah Tabligh memiliki ciri-ciri diantaranya bersifat tektual, dan berpegang pada akidah Ahlus Sunnah wal Jama'ah dan bermazhab Syafi'i. Tradisionalisme di Indonesia tidak bersifat radikal seperti yang terjadi di Turki dan Pakistan. Tradisionalisme di Indonesia bersifat lebih moderat dan akomodatif terhadap berbagai persoalan termasuk persoalan agama.

\section{B. Sejarah Munculnya}

\section{Tradisionalisme Islam di Indonesia}

Sebelum menjelaskan sejarah munculnya tradisionalisme di Indonesia, terlebih dahulu akan dikemukakan munculnya tradisionalisme secara umum. Paham tradisional --sebagaimana terlihat dalam sejarah-- merupakan fenomena umum yang terjadi secara merata di seluruh dunia Islam. Di Saudi Arabia tradisionalisme cenderung "mengawetkan" tradisi pendahulunya secara tidak kritis. Berbagai praktek tradisi seperti berziarah, berdo'a dan minta-minta kepada kuburan yang dianggap keramat. Praktek perdukunan dengan menggunakan jampi-jampi dan jimat-jimat yang membawa kepada perbuatan syirik pernah mewarnai masyarakat Arab di abad ke-18 M. Akibatnya, praktek kaum tradisionalis tersebut mendapat reaksi keras dari Gerakan Wahabiyah.

Seiring dengan itu, praktek Islam tradisional juga dijumpai di India, Mesir, Turki, termasuk di Indonesia. Di Indonesia kelompok tradisional menentang kaum modernis dan nasionalis, terutama dalam bidang kemasyarakatan dan politik. Untuk lebih memperkokoh sosialisasi paham tradisionalnya itu mereka mendirikan lembaga-lembaga pendidikan yang hanya mengajarkan pengetahuan agama, tanpa bekerja sama dengan pihak asing seperti Inggris. Akibatnya pendidikan kelompok tradisionalis cenderung terbelakang baik dari segi mutu, sarana, dan lain sebagainya. Lulusan lembaga pendidikan tradisional umumnya kurang mendapat tempat bekerja di kantor-kantor pemerintahan, karena tidak memiliki keahlian yang diharapkan. (Ziauddin Alavi, 1983: 134)

Sementara itu kelompok tradisionalis di Mesir terlihat ketika 
memperhatikan kemajuan-kemajuan yang dibawa Napoleon Bonaparte. Akibatnya kelompok tradisionalis merasa heran melihat kemajuan yang dibawa Napoleon. Sehingga sebagian mereka mengubah pandangannya untuk menyesuaikan diri dengan tuntutan zaman. Di samping itu ada yang tetap bertahan dalam sikap dan pandangan tradisionalnya.

Selanjutnya, kelompok tradisionalis di Turki mengambil bentuk dengan sikap menentang segala kebijakan pemerintah yang dianggap bertentangan dengan syari'at, dalam arti dengan ketentuan hukum yang ditetapkan para ulama fiqh. Namun usaha yang dibentuknya ternyata tidak membawa hasil yang memuaskan, sehingga Turki pernah menjadi negara sekuler.

Kaum tradisionalis dengan ciri-cirinya di atas ternyata dijumpai pula dalam masyarakat Indonesia, khususnya di pedesaan. Kebanyakan mereka mengambil sikap menentang berbagai hal yang berbau modern atau yang berasal dari Barat. Agaknya, pembangunan adanya pondokpondok pesantren merupakan sikap antisipasi terhadap serangan westernisasi. Ciri dan karakter pondok pesantren adalah menggunakan kitabkitab klasik secara tekstual, seperti dalam bidang fiqh diajarkan kitab karangan Imam Syafi'i, dalam bidang teologi diajarkan kitab karangan Imam Sanusi dan Imam Abu Hasan AlAsy'ari, dalam bidang tasawuf diajarkan kitab-kitab karangan Imam al-Ghazali. Sedangkan kajian filsafat, ilmu pengetahuan modern dan teknologi tidak diajarkan pada Pesantren. Namun hal yang dibanggakan adalah kemajuan dalam ilmu agama dan sikap spiritual yang mendalam. Sedangkan dalam bidang ilmu pengetahuan dan etos kerja cendrung rendah dan kurang diminati.
Sikap tradisionalis yang berbasis pada masyarakat pedesaan tersebut sebagian besar dilindungi melalui organisasi keagamaan, khususnya Nahdatul Ulama, (Lihat : Abuddin Nata, 2001: 148-149) walaupun belakangan ini julukan NU sebagai organisasi kalangan Islam tradisionalis sudah kurang cocok lagi. Begitu juga Persatuan Tarbiyah Islamiyah (Perti), (Lihat: Tim Penyusun IAIN Syahid, t.th.: 766, dan juga Chairusdi, 1999: 48-79) mengikuti aliran Ahlus Sunnah wal Jama'ah dalam i'tikad dan mazhab Syafi'i dalam syari'at dan ibadat. Termasuk organisasi al-Washliyah alJami'ah, disebut: al-Washliyah, (Lihat: Chairusdi, 1999: 85) berasaskan Islam dan bermazhab Syafi'i serta berhaluan Ahlus Sunnah wal Jama'ah.

Melihat rentang sejarah tentang tradisionalisme dalam dunia Islam, ternyata bentuk tersebut selalu diminati masyarakat yang cendrung terbelakang dari sistem pendidikan dan pemahaman. Pola ini haruslah di"re-interpretasi" untuk menuju kehidupan yang lebih progresif.

\section{Paham dan Gerakan \\ Tradisionalisme Islam di Indonesia}

Di samping organisasi keagamaan seperti: Nahdatul Ulama (NU), Persatuan Tarbiyah Islamiyah (Perti), dan Al-Washliyah, masih ada gerakan-gerakan lainnya yang memiliki corak yang sama. Gerakan tersebut adalah Jama'ah Tabligh. Jama'ah Tabligh memiliki ciri-ciri sebagai berikut:

1. Pengamalan ibadah yang kuat, seperti shalat, zikir, dan ibadah lainnya. Pada umumnya Jama'ah Tabligh sangat intens dalam mengajak umat untuk mengamalkan ajaran agama. 
2. Pola berpakaian cenderung meniru sistem yang dilakukan oleh Nabi dan sahabat serta masyarakat Arab lainnya.

3. Dari segi sosiologis, cenderung hidup dengan sistem kelompok. Mereka selalu mendatangi rumahrumah untuk bersilaturrahmi.

4. Dari segi pemahaman agama, bersifat harfiah atau literal. Apa yang dianggap sunnah diamalkan dengan konsekuen. Buku yang mengandung hadits-hadits fadail amal (keutamaan amal) sangat dianjurkan, seperti: keutamaan shalat sunat, shalat berjama'ah, berzikir, membaca al-Qur'an, bershalawat, dan keuta-maan membaca tasbih, tahlil dan tahmid. (Abuddin Nata, 2001: 150).

Melihat ciri-ciri tersebut dapat dipahami bahwa Jama'ah Tabligh, di samping mengandung segi-segi positif, juga mengandung sisi negatif. Segi positif, berupa ketaatan, kepatuhan dan kesungguhan menjalankan ibadah shalat lima waktu serta upaya mendekatkan diri kepada Tuhan. Sedangkan segi negatif, sikap mereka yang memahami Islam hanya pada aspek ibadah ritual saja. Hal tersebut kurang tepat, karena ajaran Islam bukan hanya ibadah bersifat ritual saja, tetapi juga sosial. Ibadah sosial mengambil bentuk berusaha mengembangkan berbagai segi kebudayaan, peradaban, ilmu pengetahuan, dan teknologi yang dibutuhkan masyarakat.

Di samping itu, ibadah sosial menjadikan umat Islam dapat meraih kemajuan yang seimbang antara urusan dunia dan akhirat, sesuai do'a yang sering dipanjatkan. Jama'ah Tabligh tampaknya mementingkan urusan akhirat saja. Sikap seperti ini membawa umat Islam maju dalam segi ibadah spiritual, tetapi terbelakang dalam bidang ilmu pengetahuan, teknologi, dan peradaban. Sehingga mengakibatkan umat Islam terjajah oleh bangsa-bangsa yang sudah maju, sebagaimana yang terjadi di abad pertengahan. Ingat, ketika India dijajah Inggris, Mesir dijajah Inggris dan Prancis, Turki dijajah Jerman dan Perancis, Malaysia dan Brunei dijajah Inggris, sedangkan Indonesia dijajah oleh Inggris, Portugis, Belanda dan Jepang. (Abuddin Nata, 2001: 151). Kelompok Jama'ah Tabligh perlu menyadari dan mengambil sikap, seimbang antara urusan dunia dan akhirat.

Kemerosotan dalam

bidang ilmu pengetahuan dan keduniaan, merupakan gejala yang diakibatkan karena mengikuti jama'ah tabligh. Seorang pelajar mengalami penurunan prerstasi belajarnya, karena waktunya dihabiskan untuk ibadah ritual dan zikir. Kalau memang begitu, alangkah suramnya masa depan pelajar tersebut. Ia tidak akan mampu bersaing menghadapi masa depannya yang penuh tantangan. Masa depan bangsa akan penuh bahaya, bila pelajar tidak mementingkan kemajuan di bidang ilmu pengetahuan, dan teknologi. Tidak aneh jika timbul dugaan, bahwa di balik gerakan jama'ah tabligh itu, terdapat missi yang membuat umat Islam mundur, terbelakang, yang akhirnya terjajah oleh bangsa lain. Artinya, Jama'ah Tabligh itu dinilai hanya kedok saja, sedangkan yang sesungguhnya ingin menghancurkan Islam melalui pintu agama, dengan cara men-dahulukan amaliyah sunnah, berdasarkan kualitas haditsnya dha'if.

$$
\text { Padahal al-Ghazali }
$$

mengemukakan ibadah ritual (agama) dan sosial itu saling terkait. Menurutnya, kewajiban setiap orang 
muslim untuk mewujudkan tertib agama, dalam arti agama bisa diwujudkan secara nyata dalam kehidupan manusia. Untuk mencapai tujuan itu tidak mungkin dilaksanakan tanpa tertib sosial. Tertib sosial dengan demikian prasyarat bagi terwujudnya tertib agama (nizam al-dunya syart li nizam al-din). Jika tertib agama adalah suatu kewajiban karena hal itu dinilai sebagai maslahah, tertib sosial sebagai prasyarat untuk dapat melaksanakan kewajiban memenuhi tertib agama, syarat tertib sosial itu pun wajib. (M. Ali Haidar, 1998: 296) Jama'ah Tabligh telah berjasa membawa anak-anak muda korban narkotika untuk bertaubat, tapi ia harus dikembalikan kepada kehidupan normal, sehingga ia tidak terisolasi dari kehidupan duniawi. Pemahaman terhadap teks hadits secara harfiah, harus diimbangi dengan memahami semangat yang terkandung dalam hadits tersebut. Ajaran menutup aurat misalnya adalah wajib, tetapi soal bagaimana bentuk dan mode pakaian tentu saja disesuaikan dengan situasi dan kondisi. Berpakaian menutup seluruh tubuh kaum wanita, bukan ajaran tetapi mode. Ajaran utamanya menutup aurat. Sedangkan aurat batasannya kondisional, yakni berbeda antara berhadapan dengan muhrim, dengan yang bukan muhrim, dengan keluarga, atau teman.

Selain Jama'ah Tabligh, Perti juga memiliki bentuk tradisionalis. Perti singkatan dari "Persatuan Tarbiyah Islamiyah". Lahirnya Perti berawal dari perjuangan Syeikh Abbas Ladang Lawas yang menentang doktrin agama yang dikembangkan oleh Kaum Muda, tetapi beliau adalah satu-satunya pemimpin Kaum Tua yang sudah menerapkan sistem pendidikan klassikal di suraunya semenjak tahun
1918. Waktu itu umumnya ulama Kaum Tua masih mempertahankan sistem pendidikan surau dan halaqah. Langkah Syeikh Abbas ini diikuti pula oleh Syeikh Sulaiman Arrasuli di surau Candung dengan mengubahnya menjadi "Madrasah Tarbiyah Islamiyah". Selanjutnya berdiri pula Tarbiyah Islamiyah di Tabek Gadang Payakumbuh dan Jaho Padang Panjang.

Pada tanggal 5 Mei 1928 diadakan pertemuan antara ketiga MTI tersebut untuk membentuk Persatuan Madrasah Tarbiyah Islamiyah (PMTI). Dua tahun kemudian (tepatnya tanggal 20 Mei 1930), organisasi PMTI diperluas menjadi Persatuan Tarbiyah Islamiyah dengan tujuan mempersatukan semua golongan tradisional. Dengan demikian, secara resmi Perti berdiri pada tanggal 20 Mei 1930.

Perti didirikan oleh ulama Minangkabau yang termasuk kelompok "Kaum Tua" seperti disebutkan di atas, sebagai reaksi terhadap perkembangan lembaga pendidikan "Kaum Muda", sebagaimana di pulau Jawa NU untuk meng-antisipasi perkembangan Muhammadiyah, al-Irsyad dan Persis. Jika NU menegas-kan paham Ahlus Sunnah wal Jam'ah, dalam bidang aqidah dan salah satu mazhab yang empat dalam bidang fiqh, Perti secara lebih tegas lagi mencantumkan mazhab Syafi'i sebagai pegangan dalam fiqh Anggaran Dasar organisasi. Hal inilah menunjukkan Perti dikategorikan sebagai tradisionalis.

Tujuan organisasi Perti dirumuskan dalam konferensinya di Bukittinggi tahun 1938 sebagai berikut:

1. Berusaha memajukan pendidikan agama Islam dan yang bersangkut paut dengan itu 
2. Menyiarkan dan mempertahankan agama Islam dari segala serangan

3. Berdaya upaya memajukan perusahaan

4. Memperkokoh amal ibadat serta memperbanyak syiarnya. (Dewan Redaksi Ensiklopedi Islam, 1999 : 97)

Dalam Anggaran Dasar Perti yang disusun pada Kongres II tanggal 3 - 5 April 1935 di Bukittinggi, ditegaskan bahwa Perti "dalam iktikad menurut paham Ahlus Sunnah wal Jama'ah dan dalam syari'at menurut mazhab Syafi'i". Sedangkan tujuan organisasi disempurnakan sebagai berikut:

1. Berusaha memajukan pengajaran agama Islam dan memperbaiki sekolah-sekolah agama bagi bangsa bumi putera seluruhnya

2. Memperkuat dan memperkokoh adat nan kawi, syarak nan lazim dalam setiap nagari

3. Memperhatikan kepentingankepentingan ulama, guru-guru sekolah agama seluruhnya, terutama sekolah-sekolah Tarbiyah Islamiyah

4. Memperkuat silaturrahmi antara sesama anggota

5. Mempertahankan agama Islam yang suci dari segala serangan. (Dewan Redaksi Ensiklopedi Islam, 1999 : 97)

Jika tujuan Perti di atas dicermati lebih jauh, nampaklah ciri Perti sebagai organisasi Islam tradisional yang mempertahankan paham Ahlus Sunnah wal Jama'ah dengan mazhab Syafi'i. Bergerak dalam bidang pendidikan agama melalui Madrasah Tarbiyah Islamiyah dan bekerjasama dengan Kaum Adat. Dengan demikian tepatlah apa yang ditulis L. Stoddard seperti kutipan berikut ini:

Pergerakan Tarbiyah Islamiyah (Perti) didirikan atas inisiatif beberapa ulama yang mempertahankan mazhab Syafi'i di Minangkabau, di antaranya Syekh Sulaiman Arrasuli, Syekh Abbas Ladang Lawas dan Abdul Wahid Tabek Gadang, berdiri pada tahun 1928 M. Perkumpulan ini bergerak dalam lapangan pendidikan Islam bekerjasama dengan golongan adat Minangkabau. (L. Stoddard, 1966: 321322)

Di bidang pendidikan agama, Perti mendorong ulama tradisional untuk memajukan pendidikan "surau" cara lama MTI di berbagai pelosok Minangkabau seperti di Lampasi, Tiakar, Batuhampar, Maninjau, Bengkawas, Padang, Solok dan Pasaman. Menurut laporan Perti, sebelum tahun 1942 Perti memiliki 350.000 orang anggota dan 45.000 orang murid yang menuntut ilmu di MTI. (Deliar Noer, 1988 : 431) Untuk mendukung program organisasi, sesuai dengan keputusan Kongres tahun 1936 di Candung, Perti menerbitkan majalah Suara Tarbiyah Islamiyah, disingkat "Suarti". Majalah inilah satu-satunya media terbitan Perti yang pertama tepat sepuluh tahun setelah organisasi ini berdiri. (Chairusdi, 1999: 59) Dengan demikian dapat dikatakan bahwa Perti merupakan gerakan tradisionalisme di Indonesia yang menekankan pada aqidah Ahlus Sunnah wal Jama'ah.

Seiring dengan Perti, NU semenjak awal berdirinya secara tegas menyatakan bahwa NU adalah organisasi ulama yang menganut paham Ahlus Sunnah wal Jama'ah. Paham ini dalam menjalankan ajaran Islam berpedoman kepada al-Qur'an dan al-Sunnah, Ijma' dan Qiyas. Sesuai penjelasan di atas, NU mengirim dua orang utusannya untuk menghadap Raja Sa'ud salah satu butir permohonannya adalah agar dalam proses pembaharuan dan gerakan modernisasi dalam Islam, termasuk 
umat Islam tetap diberi kebebasan menganut salah satu mazhab yang empat yakni Hanafi, Syafi'i, Maliki atau Hanbali. Dalam perkembangannya hingga saat ini, NU termasuk yang mempraktekkan paham dari mazhab Syafi'i.

K. H. Bisri Mustofa seorang ulama asal Rembang mengartikan Ahlu Sunnah wal Jama'ah sebagai paham yang berpegang teguh kepada tradisi, sebagai berikut:

a. Dalam bidang Hukum-hukum Islam, menganut salah satu ajaran dari empat mazhab (Hanafi, Maliki, Syafi'i, dan Hanbali). Dalam prakteknya para Kiyai merupakan penganut kuat mazhab Syafi'i.

b. Dalam soal Tauhid, menganut ajaran-ajaran Imam Hasan alAsy'ariy dan Imam Mansur alMaturidiy.

c. Dalam bidang Tasawuf, menganut dasar-dasar ajaran Imam $\mathrm{Abu}$ Qasim al-Junaid. (Abuddin Nata, 2001 : 144)

kezuhudan ulama NU dalam menjalankan ajaran pahamnya, mendapatkan tempat di hati yang selalu diikuti dan ditaati jama'ahnya. Hal ini, nampaknya menjadi tradisi yang mengakar dari jama'ah NU. Secara tegas Kiyai Achmad Shiddiq memberi komentar: "penghormatan yang amat tinggi terhadap para ulama, merupakan refleksi dari tradisi berpikir yang menggunakan mazhab. Bermazhab bagi NU merupakan hal yang mutlak." (Abuddin Nata, 2001 : 148)

Sehingga dewasa ini, NU tetap mempertahankan secara turun temurun, tradisi yang diajarkan pendirinya. Dalam mengembangkan pendidikan, tokoh NU banyak yang berkiprah melalui Pondok Pesantren, di samping tetap mengemban tugas dalam pengembangan

bidang ekonomi maupun politik.

Gerakan trasionalisme lainnya di Indonesia dianut oleh alWashliyah. Al-Washliyah atau alJami'ah Washliyah didirikan di Medan pada tahun 1930 atas inisiatif pelajar Maktab Islamiyah Tapanuli yang tergabung dalam kelompok "Debating Club".(Dewan Redaksi Ensiklopedi Islam, 1999 : 303 ). Organisasi ini secara tegas menyatakan keterikatannya dengan paham Ahlus Sunnah wal Jama'ah dan fiqh Mazhab Syafi'i. (Zamakhsyari Dhofier, 1999 : 385 ). Menurut Deliar Noer, AlWashliyah sangat aktif mengajak orang Batak menganut agama Islam dan dipandang sebagai organisasi yang mampu menandingi misionaris Kristen di Sumatera Utara. (Deliar Noer, 1988 : 266)

Kepengurusan

$\mathrm{Al}-$

Washliyah periode pertama terdiri dari Ismail Banda dan Abdurrahman Sihab (Ketua), M. Arsyad Thalib Lubis dan Adnan Nur (Sekretaris). M. Ya'cub (Bendahara), Syekh Muhammad Yunus (Penasehat) serta $\mathrm{H}$. Syamsuddin dan H.A. Malik sebagai anggota. Kepengurusan ini disahkan oleh Kesultanan Deli dan Pemerintah Hindia Belanda. (Dewan Redaksi Ensiklopedi Islam, 1999 : 303)

Dalam bidang organisasi, Al-Washliyah banyak mengambil contoh kepada Muhammadiyah seperti membentuk majelis dan organisasi otonom. Ada tiga majelis yang melaksanakan program organisasi, yaitu Majelis Penyiaran dan Dakwah Islam, Majelis Pendidikan dan Pengajaran, serta Majelis Penyantunan. Organisasi otonom adalah Muslimat alWashliyah, Angkatan Puteri, Gerakan Pemuda al-Washliyah, Ikatan Pelajar al-Washliyah, Ikatan Guru alWashliyah dan Ikatan Sarjana alWashliyah. Semenjak tahun 1986 
Pengurus Besar dipindahkan dari Medan ke Jakarta dan sampai tahun 1990 Al-Washliyah telah berdiri pada 18 propinsi. (Dewan Redaksi Ensiklopedi Islam, 1999 : 304).

Dalam bidang pendidikan, al-Washliyah juga menerapkan sistem pendidikan seperti yang dicontohkan oleh Muhammadiyah, yaitu mendirikan sekolah-sekolah. Di bidang dakwah, organisasi ini bekerja sama dengan organisasi Islam yang lain. Al-Washliyah juga mendirikan Panti Asuhan yang dikelola oleh Majelis Penyantunan. (Dewan Redaksi Ensiklopedi Islam, 1999 : 304). Di bidang politik, al-Washliyah yang menyatakan diri sebagai organisasi yang independen, tapi tokohtokohnya banyak yang aktif di Partai Islam Masyumi pada zaman Orde Lama. (Dewan Redaksi Ensiklopedi Islam, 1999 : 304).

$\begin{array}{ll}\text { Bila dibandingan al- } \\ \text { Washliyah } & \text { dengan }\end{array}$ Muhammadiyah dan Perti terlihat ada sisi-sisi persamaan dan perbedaannya, antara lain:

1. Dalam bidang aqidah, alWashliyah sama dengan NU dan Perti, yaitu sama-sama menganut paham Ahlus Sunnah wal Jama'ah

2. Dalam bidang fiqh, al-Washliyah sama dengan Perti, memegang teguh mazhab Syafi'i.

3. Dalam bidang pendidikan, dakwah dan sosial-politik, al-Washliyah sama dengan Muhammadiyah: mendirikan sekolah-sekolah, panti asuhan dan independen dalam politik. Berbeda dengan NU dan Perti yang menyatakan diri sebagai partai politik tersendiri.

Oleh karena itu tepatlah kiranya apa yang ditulis oleh Zamakhsyari Dhofier yang menyebutkan Al-Washliyah sebagai koreksi atas sistem klasifikasi dikhotomis Islam Indonesia ke dalam kategori tradisional dan modern.
(Zamakhsyari Dhofier, 1999 : 385). Di samping itu, penekanan terhadap aqidah Ahl al-Sunah wa al-Jamaah dan fiqh mazhab Syafi'i merupakan bukti bahwa al-Washliyah termasuk kelompok tradisionalisme Islam di Indonesia.

\section{DAFTAR KEPUSTAKAAN}

Ahmad, Baharuddin, Tradisionalisme Islam, Pewawancara: Budi Munawar-Rachman,__ Jurnal Ulumul Qur'an, Vol III No. 3, 1993

Alavi, Ziauddin, Islamic Educational Thought in Middle Ages, India : Hederadab, 1983

Chairusdi, Sejarah Perjuangan dan Kiprah PERTI dalam Dunia Pendidikan Islam di Minangkabau, Padang: IAIN IB Press, 1999

Dewan Redaksi Ensiklopedi Islam, Ensiklopedi Islam, Jakarta: Ichtiar Baru Van Hoeve, 1999, jilid II dan IV

Dhofier, Zamakhsyari, "Konsolidasi Tradisionalisme",

Ensiklopedi Tematis Dunia Islam Asia Tenggara, Jakarta: Ichtiar Baru Van Hoeve, 1999

Echols, John M., dan Hassan Shadily, Kamus Inggris Indonesia, Jakarta: Gramedia, 1979, cet. XII

Ecip, S. Sinansari, NU, Khittah, dan Godaan Politik, Bandung: Mizan, 1994, cet. I

Haidar, M. Ali, Nahdatul Ulama dan Islam di Indonesia, Pendekatan Fikih dalam Politik, Jakarta: PT. Gramedia Pustaka Utama, 1998, cet. kedua

Munawwir, Ahmad Warson, Al-Munawwir Kamus Arab-Indonesia, Surabaya: Pustaka Progressif, 1997. cet. XIV 
Nasr, Sayyed Hossein, Islam Tradisi di Tengah Kancah Dunia Modern, Bandung: Pustaka, 1994

Nata, Abuddin, Peta Keragaman Pemikiran Islam di Indonesia, Jakarta: PT. Raja Grafindo Persada, 2001, cet. ke-1

Noer, Deliar, Gerakan Modern Islam di Indonesia 1900 - 1942, Jakarta: LP3S, 1988, cet. IV

, Partai Islam di Pentas Nasional 1945-1965, Jakarta: PT. Pustaka Utama Grafiti, 1987, cet. ke-1

Poerwadarminta, WJS., Kamus Umum Bahasa Indonesia, Jakarta: Balai Pustaka, 1991, cet. XII

Rahman, Fathur, Ikhtisar Musthalahul Hadits, Bandung : Al-Ma'arif, 1981, cet. I

Saefuddin, Didin, Pemikiran Modern dan Postmodern Islam, Biografi Intelektual 17 Tokoh, Jakarta: Grasindo, 2003

Shadily, Hasan, Ensiklopedi Indonesia, Jakarta: Ichtiar Baru Van Hoeve, 1984

Stoddard, L., Dunia Baru Islam, penerjemah: Mulyadi Djojomartono, Jakarta: Panitia Kesra, 1966

Tim Penulis IAIN Syahid, Ensiklopedi Islam Indonesia, Jakarta: Djambatan, t.th. 